Ege Tıp Dergisi / Ege Journal of Medicine 2021; 60 (1): 76-82

\title{
Koroner arter hastalığında magnezyum/fosfat oranı ile endotel fonksiyonları arasındaki ilişki: Bir prospektif çalışma
}

\author{
Relationship between magnesium / phosphate ratio and endothelial function in \\ coronary artery disease: A prospective study \\ Elton Soydan (D) Mustafa Akın (D) \\ Ege Üniversitesi Tıp Fakültesi, Kardiyoloji Anabilim Dalı, İzmir, Türkiye
}

\section{ÖZ}

Amaç: Aterosklerotik değişikliklerin ve endotel disfonksiyonunun patogenezi karmaşık ve çok faktörlüdür. Kandaki elektrolitlerden magnezyum ve fosfat mineralleri aterogenez ve endotel fonksiyon bozukluğunun patofizyolojisinde yer alan önemli minerallerdir. Endotel fonksiyonu değerlendirmede en çok kabul görmüş akım aracılı vazodilatasyon testidir. Çalışmamızda, koroner arter hastalığı olan hastalarda magnezyum/fosfat oranı ile endotel fonksiyonları arasındaki ilişkinin değerlendirilmesi amaçlanmıştır.

Gereç ve Yöntem: Koroner anjiyografi ile belgelenmiş koroner arter hastalığı olan ardışık 61 hasta çalışmaya dahil edildi. Radial arterden akım aracılı vazodilatasyon testi ile endotel fonksiyonları poliklinik kontrolünde incelendi. Magnezyum/fosfat oranı ile akım aracılı vazodilatasyon yüzdelik değişimi arasındaki korelasyonu değerlendirmek için Spearman korelasyon analizi kullanıldı.

Bulgular: Hastaların ortalama yaşı 61,2 $\pm 10,1$ yıl olup hastaların \%72'si erkek ve ortalama vücut kitle indeksi $27,8 \pm 5,4 \mathrm{~kg} / \mathrm{m}^{2}$ dir. AAD testinde ortalama radial arter bazal çapı $0,25 \pm 0,03 \mathrm{~cm}$, test sonrası ortalama radial arter çapı $0,28 \pm 0,03 \mathrm{~cm}$ olarak saptandı. Magnezyum/fosfat oranları ile endotel fonksiyonlarını gösteren arter çapındaki yüzdelik değişim arasında pozitif yönde bir ilişki saptandı $(r=$ $0,268, p=0,037)$.

Sonuç: Koroner arter hastalığı olan hastalarda, magnezyum/fosfat oranı endotel fonksiyonlarının bir göstergesi olarak kullanılabilir.

Anahtar Sözcükler: Koroner arter hastalığı, endotel fonksiyonu, magnezyum, fosfat.

Bu çalışma 3-6 Aralık 2020 tarihlerinde çevrimiçi olarak gerçekleştirilen 36. Uluslararası Katıımlı Türk Kardiyoloji Kongresinde sözlü bildiri olarak sunulmuştur.

\begin{abstract}
Aim: The pathogenesis of atherosclerotic changes and endothelial dysfunction is complex and multifactorial. Magnesium and phosphate minerals are important blood minerals in the pathophysiology of atherogenesis and endothelial dysfunction. Flow-mediated vasodilation test is known as one of the most valuable examination in evaluation of endothelial functions. Our study's aim was to evaluate the relationship between magnesium / phosphate ratio and endothelial functions in patients with coronary artery disease.

Materials and Methods: Sixty-one patients who had had coronary angiography and diagnosed with coronary artery disease were consecutively included. Endothelial functions were evaluated by flowmediated vasodilation test on the radial artery during outpatient visit. Spearman correlation was used to evaluate the correlation between the $M g$ / P ratio and the FMD percentile change.
\end{abstract}

\footnotetext{
Sorumlu yazar: Elton Soydan

Ege Üniversitesi Tıp Fakültesi, Kardiyoloji Anabilim Dalı,

İzmir, Türkiye

E-posta: eltonsoydan@hotmail.com

Başvuru tarihi: 11.01.2021 Kabul tarihi: 25.01.2021
} 
Results: Mean age of patients was $61.2 \pm 10.1$ years, and $72 \%$ of the patients were male and the mean body mass index was $27.8 \pm 5.4 \mathrm{~kg} / \mathrm{m}^{2}$. In the flow-mediated vasodilation test, the mean radial artery basal diameter was $0.25 \pm 0.03 \mathrm{~cm}$, and the mean radial artery diameter after FMD was $0.28 \pm$ $0.03 \mathrm{~cm}$. A positive correlation was observed between magnesium / phosphate ratio and the percentage change in artery diameter implying endothelial functions $(r=0.268, p=0.037)$.

Conclusion: In patients with coronary artery disease, magnesium / phosphate ratios can be used as a parameter reflecting endothelial function.

Keywords: Coronary artery disease, endothelial function, magnesium, phosphate.

This study is presented as an online oral presentation in the 36th Turkish Cardiology Congress with International Participation on December 3th-6th 2020.

\section{GíRiş}

Endotel, kan ve dokular arasında pasif bir bariyer olup, vazokonstriktör ve vazodilatatörlerin sentezini dengeler. Bu şekilde vasküler bütünlüğünü koruyarak kardiyovasküler sistem hastalıklarında büyük önem arz etmektedir (1). Endotel disfonksiyonu ise, kardiyovasküler hastalıklarla $(\mathrm{KVH})$ sonuçlanan aterosklerozun ana nedenlerinden biridir (2). Aterosklerotik değişikliklerin ve endotelyal fonksiyondaki bozuklukların patogenezi birçok nedene bağlı gelişmektedir.

Kanda bulunan elektrolitlerden Magnezyum (Mg) ve Fosfat (P) mineralleri aterogenez patofizyolojisinde yer alan önemli minerallerdir. Magnezyum, endotel fonksiyonu, damar tonusunun düzenlenmesi ve miyokardiyal uyarılabilirlik gibi kardiyovasküler fonksiyonları düzenleyen birçok süreçte önemli rol oynamaktadır $(3,4)$. Dolaşımdaki yüksek $\mathrm{Mg}$ düzeylerinin ve $\mathrm{Mg}$ alımının, koroner kalp hastalığı da dahil olmak üzere $\mathrm{KVH}$ riskinde rölatif bir azalma ile ilişkili olduğu gösterilmiştir (5, 6). Düşük $\mathrm{Mg}$ seviyelerinin ise, endotelyal hücre fonksiyon bozukluğunu ve potansiyel olarak tromboz ve ateroskleroz riskini arttırabildiği gösterilmiştir (7). Diğer yandan, yüksek serum $P$ konsantrasyonunun, endotel disfonksiyonu ve mortalite ile ilişkili olduğu bildirilmiştir $(8,9)$. Normal aralık dahilinde olsa bile yüksek serum $P$ konsantrasyonunun, normal böbrek fonksiyonu olan hastalarda ateroskleroz ve mortalite gelişiminde ön gördürücü olduğu bildirilmiştir (8, 10). $\mathrm{Bu}$ elementlerin dengede tutulması ile kardiyovasküler risk faktörlerinin azaltılması sonucunda, KVH tedavisinde önemli terapötik fayda sağlayabileceği öne sürülen endotel fonksiyonları düzeltilebilmektedir $(11,12)$.

Akım aracılı vazodilatasyon testi (AAD) ise endotel fonksiyonları değerlendirmede kabul görmüş yöntemlerden birisidir (13). Bu çalışmada, endotel fonksiyonunda rol oynayan $M g$ ve $P$ elementlerinin AAD ile ilişkisinin olup olmadığının araştırılması amaçlanmıştır. Bu şekilde, ultrasonografik yönteme gerek duyulmadan kanda bakılan bu elementlerinin değerlendirilmesi ile endotel fonksiyonları hakkında bilgi edinilebilecektir ve hastaların $\mathrm{KVH}$ takibinde daha kolay, düşük maliyetli yollardan önemli bilgiler sağlanabilecektir.

\section{GEREÇ VE YÖNTEM}

Çalışma tek merkezli, prospektif, gözlemsel olarak tasarlanmıştır. Koroner anjiyografi ile belgelenmiş koroner arter hastalığı olan Eylül 2017- Şubat 2018 tarihleri arasında kontrol amaçlı kardiyoloji polikliniğine başvuran ardışık 61 hasta çalışmaya dahil edilmiştir. Hastalara çalışma ile ilgili detaylı bilgi verildikten sonra imzalı gönüllü onam formları alınmıştır. Radial arterden nabız alınamayan, optimal ultrasonografik inceleme yapılamayan, son altı ay içinde radial yolla anjiyografi/perkütan girişim uygulanan hastalar ve bilgilendirilmiş gönüllü onam vermeyen hastalar dahil edilmemiştir. Hastalara ait demografik veriler, biyokimyasal parametreler ve görüntüleme bulguları kaydedilmiştir. Hastaların başvuru esnasındaki serum $\mathrm{Mg}$ ve $\mathrm{P}$ düzeylerinin oranı esas alınmıştır. Çalışma popülasyonunda endotel fonksiyonlarının değerlendirilmesinde en sık kullanılan non-invazif tanı testi olan AAD testi uygulanmıştır. Çalışmamızın etik kurul onayı 26.12.2017 tarihinde 17-12.1/22 karar numarası ile alınmıştır.

\section{Akım aracılı vazodilatasyon testi}

Akım aracılı vazodilatasyon testi, radial arter üzerine yerleştirilen 11L-D, 4.5-12 MHz problu ultrason cihazı (GE Healthcare Vivid E9 4D Cardiovascular ultrasound system, Norway) ile yapılmıştır. İşlem sessiz ve aydınlık bir ortamda yapılmıştır. Hastalar işlemden 30 dakika öncesine kadar işlemi etkileyebilecek kafein, sigara veya çay gibi ürünler tüketmemiş olarak AAD testine tabi tutulmuşlardır. En az 10 dakika boyunca hastalar sessiz ve aydınlık bir ortamda 
dinlendirilmişlerdir. İşlemin yapılacağı üst kola bağlanan manşon 5 dakika boyunca 220 mmHg'lık bir basınç ile şişkin vaziyette kaldıktan sonra hızla söndürülmüştür. Maksimum dilatasyon manşon söndürüldükten sonra 3 dakika boyunca ultrasonografik yöntem ile kaydedilmiştir.

Radial arter AAD yüzdelik değişimi aşağıdaki formül ile hesaplanmıştır:

$A A D=(\%)$ (Reaktif Hiperemi Sonrası Cap - Bazal arter çapı $)$

\section{Bazal arter çapı}

Radial arter çapı, damarın ön duvar intima tabakasından, arka duvar intima tabakasına kadar santimetre $(\mathrm{cm})$ cinsinden ölçülen mesafeyle elde edilmiştir. Ölçümler elektrokardiyografi eşliğinde kardiyak siklus belirlenerek diyastol sonunda alınmıştır. Radial arter bazal çapı, AAD sonrası çap ve yüzdelik değişimi kayıt altına alınmıştır. Tüm hastaların ultrasonografik değerlendirmesi çalışmadan habersiz olarak tek bir hekim tarafından yapılmıştır.

\section{Istatistiksel analiz}

IBM SPSS Statistics 25.0 Programı kullanılmıştır. Nümerik değişkenlerin normal dağılıma uygunluğu Kolmogorov-Smirnov $(n>=50)$ testiyle incelenmiştir. Nümerik değişkenler ortalama ve standart sapma veya medyan (min.-maks.) olarak verilmiştir. Kategorik değişkenler sayı ( $n$ ) ve yüzde (\%) olarak verilmiştir. Normal dağılıma uygunluk sağlanmadığından bazal çap sonrası çap değişimi için Wilcoxon testi kullanılmıştır. Nümerik değişkenler için korelasyon analizi (Spearman korelasyon analizi) yapılmıştır. Mg/P oranları ile $A A D$ yüzdelik değişimi arasındaki korelasyonu değerlendirmek için Spearman korelasyon analizi kullanılmıştır. Tüm hipotezler için anlamlılık düzeyi 0.05 kabul edilmiştir.

\section{BULGULAR}

Hastalarla ilgili demografik özellikler Tablo-1'de özetlenmiştir. Hasta popülasyonunun ortalama

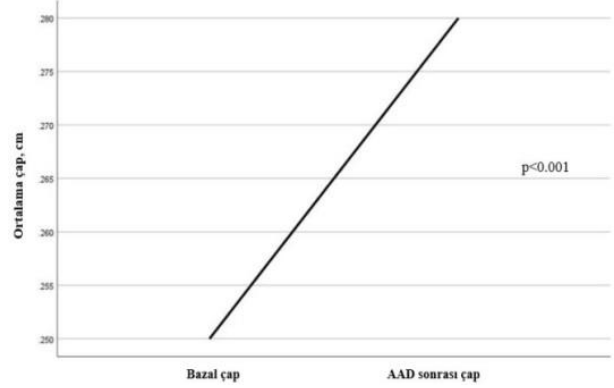

Şekil-1. Akım aracılı vazodilatasyon testinde radial arter çap değişim grafiği. yaşı $61,2 \pm 10,1$ yıl olup erkek cinsiyet baskındır $(\% 72)$. Ortalama vücut kitle indeksi (VKI) $27,8 \pm 5,4 \mathrm{~kg} / \mathrm{m}^{2}$ olarak bulunmuştur.

Hastaların \%26,2'sinde sigara kullanım öyküsü, $\% 21,3$ 'ünde ise alkol kullanım öyküsü vardı. Hipertansiyon $(\% 80,3)$ en çok görülen yandaş hastalık olarak bulunmuştur. Diabetes mellitus ve hiperlipidemi ise sırasıyla \%41 ve \%39,3 olarak belirlenen yandaş hastalıklardır.

Hastalara ait laboratuvar ve görüntüleme bulguları Tablo-2'de özetlenmiştir. Biyokimyasal parametrelerden ortalama LDL değeri 100,81 $( \pm 38,76) \mathrm{mg} / \mathrm{dl}$, ortalama hemoglobin $(\mathrm{Hb})$ değeri $13,43( \pm 2,22) \mathrm{g} / \mathrm{dl}$ ve ortalama açlık glikoz değeri $131,63( \pm 59,35) \mathrm{mg} / \mathrm{dl}$ olarak bulunmuştur. Hastaların ortalama $\mathrm{Mg}$ değeri $1,99 \quad( \pm 0,28)$ $\mathrm{mg} / \mathrm{dl}$, ortalama $P$ değeri $3,36( \pm 0,54) \mathrm{mg} / \mathrm{d}$ olarak bulunmuştur. Yapılan ekokardiyografide hastaların ortalama sol ventrikül ejeksiyon fraksiyonu (LVEF) değeri $\% 52,8 \pm 9,7$ ve sol atrium (LA) çapı $3,9 \pm 0,7 \quad \mathrm{~cm}$ şeklinde hesaplanmıştır.

Akım aracılı vazodilatasyon testi bulguları Tablo3'te özetlenmiş olup radial arter çap değişim grafiği Şekil-1'de gösterilmiştir. Akım aracılı vazodilatasyon testinde hiperemi sonrası 3 dakika boyunca yapılan ölçümlerde en yüksek arter çapı baz alınmıştır. Ortalama radial arter bazal çapı $0,25( \pm 0,03) \mathrm{cm}$, AAD sonrası ortalama radial arter çapı $0,28 \quad( \pm 0,03) \mathrm{cm}$ saptanmıştır $(p<0,001)$. AAD sonrası radial arter yüzdelik çap değişimi ortalama \% 12,34 $( \pm 3,03)$ saptanmıştır.

Mg/P oranları ile AAD yüzdelik değişimi arasındaki ilişki Şekil-2'de gösterilmiştir. Çalışmaya dahil edilen hastaların ortalama $\mathrm{Mg} / \mathrm{P}$ oranı $0,61( \pm 0,13)$, ortalama değeri ise 0,62 (minimum 0,20- maksimum 1,03) olarak bulunmuştur. Mg/P oranları ile $A A D$ testinde endotel fonksiyonlarını gösteren arter çapındaki yüzdelik değişim arasında pozitif yönde bir ilişki bulunmuştur $(r=+0,268, p=0,037)$.

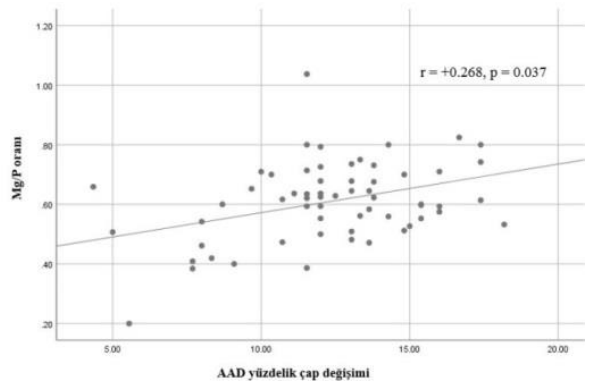

Şekil-2. Magnezyum/Fosfat oranları ile AAD yüzdelik çap değişim arasındaki ilişki. 
Tablo-1. Çalışma popülasyonunun demografik özellikleri.

\begin{tabular}{ll}
\hline Demografik özellikler & $\mathbf{n = 6 1}$ Ortalama (士 standart sapma) \\
\hline Yaş, yıl & $61,2 \pm 10,1$ \\
Erkek cinsiyet, n (\%) & $44(72,1)$ \\
VKi (kg/m²) & $27,8 \pm 5,4$ \\
Sistolik KB, mmHg & $141,7 \pm 18,4$ \\
Diyastolik KB, mmHg & $79,9 \pm 13,6$ \\
Kalp hızı, /dk & $77,5 \pm 18,1$ \\
Sigara, n (\%) & $16(26,2)$ \\
Alkol kullanımı, n (\%) & $13(21,3)$ \\
Hipertansiyon, n (\%) & $49(80,3)$ \\
Diyabetes mellitus, n (\%) & $25(41,0)$ \\
Hiperlipidemi, n (\%) & $24(39,3)$ \\
AF, n (\%) & $2(3,3)$ \\
Periferik arter hastalığı, n (\%) & $7(11,5)$ \\
KOAH, n (\%) & $5(8,2)$ \\
Anemi, n (\%) & $6(9,8)$ \\
Kronik KY, n (\%) & $6(9,8)$ \\
KBY, n (\%) & $4(6,6)$ \\
Tiroid hastalığı, n (\%) & $3(4,9)$ \\
İnme, n (\%) & $1(1,6)$ \\
\hline *KB: kan basıncı; NYHA: New York Kalp Cemiyeti; VKi: vücut kitle indeksi AF: atriyal fibrillasyon; KBY: kronik böbrek yetmezliği; &
\end{tabular}
KOAH: kronik obstruktif akciğer hastalığı; KY: kalp yetmezliği

Tablo-2. Hastaların laboratuvar ve görüntüleme bulguları.

\begin{tabular}{ll}
\hline Parametre & Ortalama ( \pm standart sapma) \\
\hline Üre, mg/dl & $36,30( \pm 18,33)$ \\
Kreatinin, mg/dl & $1,07( \pm 0,81)$ \\
Total kolesterol, mg/dl & $173,44( \pm 43,49)$ \\
HDL, mg/dl & $43,34( \pm 10,75)$ \\
LDL, mg/dl & $100,81( \pm 38,76)$ \\
Beyaz küre, k/mm3 & $8,29( \pm 2,43)$ \\
Hemoglobin, g/dl & $13,43( \pm 2,22)$ \\
Açlık glukoz, mg/dl & $131,63( \pm 59,35)$ \\
TSH, mU / & $2,01( \pm 1,46)$ \\
Mg, mg/dl & $1,99( \pm 0,28)$ \\
P, mg/dl & $3,36( \pm 0,54)$ \\
Mg/P & $0,61( \pm 0,13)$ \\
LVEF, \% & $52,8( \pm 9,7)$ \\
LA, cm & $3,9( \pm 0,7)$ \\
\hline
\end{tabular}

*HDL: yüksek dansiteli lipoprotein; Ivsd: interventriküler septum diyastol; LA: sol atrium; LDL: düşük dansiteli lipoprotein; LVEF: sol ventrikül ejeksiyon fraksiyonu; Mg: magnezyum, P: fosfat; TSH: tiroit uyarıcı hormon.

Tablo-3. Akım aracılı vazodilatasyon (AAD) testi.

\begin{tabular}{lllll}
\hline AAD testi & Bazal çap & $\begin{array}{l}\text { AAD } \\
\text { sonrası çap }\end{array}$ & $\begin{array}{l}\text { AAD sonrası yüzdelik çap } \\
\text { değişimi }\end{array}$ & P değeri \\
\hline $\begin{array}{l}\text { Ortalama } \\
( \pm \text { standart sapma }) \mathrm{mm}\end{array}$ & $0,25( \pm 0,03)$ & $0,28( \pm 0,03)$ & $12,34( \pm 3,03)$ & $<0,001$ \\
\hline
\end{tabular}




\section{TARTIŞMA}

Sistemik endotel disfonksiyonu, ateroskleroz, hipertansiyon ve $\mathrm{KVH}$ patogenezinde tetikleyici bir olaydır (14). Endotel disfonksiyonunu gösteren endotel bağımlı vazodilatasyon kaybı yapısal aterosklerotik lezyonlardan önce gelmektedir $(15,16)$. Akım aracılı vazodilatasyon testi, ateroskleroz ve diğer kardiyovasküler hastalıklar için risk altında olan hastalarda makrovasküler endotel fonksiyonunu değerlendirmek için geçerli bir yöntem olmakla birlikte en yaygın kullanılan non-invazif testlerden biridir (13). Endotel fonksiyonlarını etkileyen birçok parametre mevcut olup bu parametreler içinde en çok kandaki mineraller önem arz etmektedir.

Magnezyumun vasküler tonusu ve yanıtı düzenlediği ayrıca asetilkolin kaynaklı endotel bağımlı vazodilatasyon için bir kofaktör görevi gördüğü bilinmektedir (17). Magnezyumun vasküler tonusu sadece endotelyal ve düz kas hücre fonksiyonlarını düzenleyerek değil, aynı zamanda nitrik oksit (NO) salınımının klasik yolunda bir rol oynayarak değiştirdiği düşünülmektedir. Yapılan bir hayvan deneyi çalışmasında Mg'nin endotelden bağımsız ve endotel bağımlı vazodilatasyonu teşvik eden prostasiklin ve NO üretimini arttırdığı gösterilmiştir (18). Magnezyum, endotele bağlı vazodilasyonu arttırarak ve vasküler direnci, oksidatif stresi ve oksitlenmiş lipitleri, inflamasyonu ve trombozu azaltarak anti-aritmik etkileri ile birlikte koroner arter hastalığına karşı potansiyel olarak koruma sağladığı gösterilmiştir (19).

Düşük $M g$ seviyelerinin, genel popülasyonda kardiyovasküler hastalık, hipertansiyon ve tromboz gelişiminde önemli bir rol oynadığı, ayrıca $\mathrm{KVH}$ patogenezinde önemli olduğu bildirilmiştir (20-22). Geleneksel kardiyovasküler risk faktörlerini kontrol ettikten sonra, daha düşük serum Mg seviyeleri takip sırasında kardiyak mortaliteyi önemli ölçüde arttırdığı bulunmuştur $(23,24)$. Stabil koroner arter hastalığı olan 50 hastanın alındığı randomize kontrollü bir çalışmada günlük $365 \mathrm{mg} \mathrm{Mg}$ takviyesinin AAD'yi önemli ölçüde iyileştirdiği gösterilmiştir (25). Magnezyum eksikliği, çeşitli hücre tiplerinde oksidatif stresi teşvik edebilmektedir (26). Koroner arter hastalığı olan düşük $\mathrm{Mg}$ düzeylerine sahip hastaları ve sıklıkla hipomagnezemiye neden olan diüretik kullanan hastaları içeren çalışmalarda $\mathrm{Mg}$ takviyesi ile endotelyal fonksiyonunda iyileşme gözlenmiştir (27). Hemodiyaliz alan son dönem böbrek yetmezliğine sahip 27 hastanın dahil edildiği kesitsel bir çalışmada AAD'nin serum magnezyumu ile pozitif yönde bir ilişki gösterdiğini ve yüksek magnezyum değerlerinin hemodiyaliz uygulanan hastalarda aslında makrovasküler endotel fonksiyonu iyileştirebileceği saptanmıştır (28).

Diğer yandan serum $\mathrm{P}$ seviyeleri normal aralıkta olsa bile yüksekliği sistemik ateroskleroz gelişimi ve karotis intima-media kalınlığı ile yakından ilişkili bulunmuştur (29). Magnezyum elementi gibi, P, NO sentez yolunun üzerindeki olumsuz etkileri nedeniyle endotel bağımlı vazomotor fonksiyonları bozarak kronik iskemik kardiyak hastalıkları ile arasındaki ilişki açıklanabilmektedir (30). Ek olarak yüksek P konsantrasyonuna maruz kalan endotelyal hücrelerde yüksek oksijen radikal oluşumu ve sonucunda NO sentezinde azalma ve apopitoz oranında artış meydana geldiği gösterilmiştir (31, 32).

$\mathrm{Bu}$ bilgiler ışığında endotel fonksiyonlarında rol oynayan bu iki elementin pratik önemini vurgulamak için çalışmamızda $\mathrm{Mg} / \mathrm{P}$ oranı kullanılmıştır. Bu oranın makrovasküler endotel fonksiyonları değerlendirmede kabul görmüş test olan AAD testi ile bir korelasyonun olup olmadığı araştırılmıştır. Testin sonucunda, Mg/P oranı ile AAD testi arasında pozitif yönde anlamlı bir ilişki olduğu saptanmıştır. Aslında, AAD testi sırasında gelişen reaktif hiperemi 'shear stress' yaratarak endotel hücrelerinde vazodilatasyon için gerekli olan NO sentezini uyarmaktadır. Bu mekanizma üzerinde hem $\mathrm{Mg}$ hem $\mathrm{P}$ etkili olması nedeniyle, $A A D$ testi ile yapılan endotel bağımlı vazomotor fonksiyonunda $\mathrm{Mg} / \mathrm{P}$ oranının doğrundan ilişkili olmasını doğrulamıştır. Bu sonuç, bir açıdan basit bir kan testi ile saptanan bu elementlerin aslında klinik öneminin büyük olduğunu göstermektedir. Çünkü, endotel fonksiyonların durumu için ultrasonografi gibi cihaza gerek duyulan AAD testi yerine $\mathrm{Mg} / \mathrm{P}$ oranının bakılması özellikle kardiyovasküler hastalıkların takibinde daha pratik ve ek bilgiler sağlayabilmektedir.

\section{Çalışma kısıtılıkları}

Çalışmamızda birkaç kısıtlılık bulunmaktadır: Hasta sayısı az ve tek merkezli bir çalışmadır. $A A D$ ve $M g / P$ seviyeleri bir defa bakılmıştır. Sağlıklı kontrol grubu düzenlenmemiş olması nedeniyle çıkan sonuçları koroner arter hastalığı olan tüm hastalarda genellemek doğru 
olmayacaktır. Bu kısıtlılıklara rağmen, literatürde koroner arter hastalığında Mg/P oranının $A A D$ testi ile doğrudan ilişkili olduğunu gösteren ilk çalışmadır.

\section{SONUÇ}

Koroner arter hastalığı olan hastalarda serum $\mathrm{Mg} / \mathrm{P}$ oranı endotel fonksiyonunun bir göstergesi olarak kullanılabilir. Koroner arter hastalığın takibinde bu oranın klinik olaylarla ne kadar ön gördürücü olduğunu saptamak için kontrollü çalışmalara intiyaç duyulacaktır.

\section{Teşekkür}

Makalemiz istatistiğinde emeği geçen Gülden Hakverdi'ye teşekkürlerimizi sunarız.

\section{Finansal Kaynak}

$\mathrm{Bu}$ makale ile ilgili herhangi bir finansal kaynaktan yararlanılmamıştır.

\section{Çıkar çatışması}

Yazarlar bu makale ile ilgili herhangi bir çıkar çatışması bulunmadığını beyan etmektedir.

\section{Kaynaklar}

1. Widlansky ME, Gokce N, Keaney JF, et al. The clinical implications of endothelial dysfunction, JAm Coll Cardiol. 2003; 42 (7): 1149-60.

2. Ross R. Atherosclerosis-an inflammatory disease. N Engl J Med. 1999; 340: 115-26.

3. Volpe SL. Magnesium, the metabolic syndrome, insulin resistance, and type 2 diabetes mellitus. Crit Rev Food Sci Nutr. 2008; 48: 293-300.

4. Kolte D, Vijayaraghavan K, Khera S, et al. Role of magnesium in cardiovascular diseases. Cardiol Rev. 2014; 22: 182-92.

5. Del Gobbo LC, Imamura F, Wu JH, et al. Circulating and dietary magnesium and risk of cardiovascular disease: a systematic review and meta-analysis of prospective studies. Am J Clin Nutr. 2013; 98: 160-73.

6. Fang $\mathrm{X}$, Liang $\mathrm{C}$, Li $\mathrm{M}$, et al. Dose-response relationship between dietary magnesium intake and cardiovascular mortality: a systematic review and dose-based meta-regression analysis of prospective studies. J Trace Elem Med Biol. 2016; 38: 64-73.

7. Maier JA, Malpuech-Brugère C, Zimowska W, et al. Low magnesium promotes endothelial cell dysfunction: implications for atherosclerosis, inflammation and thrombosis. Biochim Biophys Acta. 2004;1689(1):13-21.

8. Tonelli M, Sacks F, Pfeffer M, et al. Cholesterol And Recurrent Events Trial Investigators. Relation between serum phosphate level and cardiovascular event rate in people with coronary disease. Circulation. 2005 ; 112 (17): 2627-33.

9. Dhingra R, Sullivan LM, Fox CS, et al. Relations of serum phosphorus and calcium levels to the incidence of cardiovascular disease in the community. Arch Intern Med. 2007; 167: 879-85.

10. Ganesh SK, Stack AG, Levin NW, et al. Association of elevated serum $\mathrm{PO}(4)$, Ca $x \mathrm{PO}(4)$ product, and parathyroid hormone with cardiac mortality risk in chronic hemodialysis patients. J Am Soc Nephrol. 2001; 12: 2131-8.

11. Vogel RA. Coronary risk factors, endothelial function, and atherosclerosis: a review. Clin Cardiol. 1997; 20: 426-32.

12. Anderson TJ, Meredith IT, Yeung AC, et al. The effects of cholesterol lowering and antioxidant therapy on endothelium-dependent coronary vasomotion. N Engl J Med. 1995; 332: 488-93.

13. Raitakari OT, Celermajer DS. Flow-mediated dilatation. Br J Clin Pharmacol. 2000; 50: 397-404.

14. Verma S, Anderson TJ. Fundamentals of endothelial function for the clinical cardiologist. Circulation. 2002; 105: 546-9.

15. McLenachan JM, Williams JK, Fish RD, et al. Loss of flow-mediated endothelium-dependent dilation occurs early in the development of atherosclerosis. Circulation. 1991; 84: 1273-8.

16. Celermajer DS, Sorensen KE, Bull C, et al. Endothelium-dependent dilation in the systemic arteries of asymptomatic subjects relates to coronary risk factors and their interaction. J Am Coll Cardiol. 1994; 24: $1468-74$.

17. Altura BM, Altura BT. New perspectives on the role of magnesium in the pathophysiology of the cardiovascular system. I. Clinical aspects. Magnesium. 1985; 4: 226-44.

18. Northcott CA, Watts SW. Low [Mg2+]e enhances arterial spontaneous tone via phosphatidylinositol 3-kinase in DOCA-salt hypertension. Hypertension. 2004; 43: 125-9. 
19. Zheltova AA, Kharitonova MV, lezhitsa IN, et al. Magnesium deficiency and oxidative stress: an update. Biomedicine (Taipei). 2016; 6: 20.

20. Kisters K, Gröber U. Magnesium in health and disease. Plant Soil. 2013; 368, 155-65.

21. Ma J, Folsom AR, Melnick SL, et al. Associations of serum and dietary magnesium with cardiovascular disease, hypertension, diabetes, insulin, and carotid arterial wall thickness: the ARIC study. J Clin Epidemiol. 1995; 48: 927-40.

22. Liao F, Folsom AR, Brancati FL. Is low magnesium concentration a risk factor for coronary heart disease? The Atherosclerosis Risk in Communities (ARIC) Study. Am Heart J. 1998; 136: 480-90.

23. Li Q, Chen Q, Zhang H, et al. Associations of Serum Magnesium Levels and Calcium-Magnesium Ratios With Mortality in Patients With Coronary Artery Disease. Diabetes Metab. 2019; 1262-3636: 30189-2.

24. Shechter M. The role of magnesium as antithrombotic therapy. Wien Med Wochenschr. 2000; 150: 343-7.

25. Shechter M, Sharir M, Labrador MJ, et al. Oral magnesium therapy improves endothelial function in patients with coronary artery disease. Circulation. 2000; 102: 2353-8.

26. Dickens BF, Weglicki WB, Li YS, et al. Magnesium deficiency in vitro enhances free radical-induced intracellular oxidation and cytotoxicity in endothelial cells. FEBS Lett. 1992; 311:187-91.

27. Cunha AR, D'El-Rei J, Medeiros F, et al. Oral magnesium supplementation improves endothelial function and attenuates subclinical atherosclerosis in thiazide-treated hypertensive women. J Hypertens. 2017; 35: 89-97.

28. Lee S, Ryu JH, Kim SJ, et al. The Relationship between Magnesium and Endothelial Function in End-Stage Renal Disease Patients on Hemodialysis. Yonsei Med J. 2016 Nov 1; 57 (6): 1446-53.

29. Onufrak SJ, Bellasi A, Shaw LJ, et al. Phosphorus levels are associated with subclinical atherosclerosis in the general population. Atherosclerosis. 2008; 199: 424-31.

30. Stevens KK, Denby L, Patel RK, et al. Deleterious effects of phosphate on vascular and endothelial function via disruption to the nitric oxide pathway. Nephrol Dial Transplant. 2017; 32: 1617-27.

31. Shuto E, Taketani Y, Tanaka R, et al. Dietary Phosphorus Acutely Impairs Endothelial Function. J Am Soc Nephrol. 2009 Jul; 20: 1504-12.

32. Peng A, Wu T, Zeng $C$, et al. Adverse effects of simulated hyper- and hypo-phosphatemia on endothelial cell function and viability. PLoS One2011; 6: e23268. 